\title{
The Impact of Social Responsibility Disclosure in Reducing the Risk in Jordanian Commercial Banks
}

\author{
Yousef Shahwan ${ }^{1} \&$ Oways Abdel-hamid ${ }^{2}$ \\ ${ }^{1}$ Accounting Department, Zarqa University, Jordan \\ ${ }^{2}$ Accounting Department, AL albait University, Jordan \\ Correspondence: Dr Yousef Shahwan, Accounting Department, Zarqa University, Jordan. E-mail: \\ yshahwan@zu.edu.jo
}

Received: May 15, 2020

Accepted: June 9, 2020

Online Published: June 16, 2020

doi:10.5430/rwe.v11n3p142

URL: https://doi.org/10.5430/rwe.v11n3p142

\begin{abstract}
This study investigates the impact of disclosure of social responsibility in reducing risks in Jordanian commercial banks. To realize the goal of this study, the researcher followed the descriptive-analytical method. The data of the study sample was gathered from the financial reports of the listed banks on the Amman Financial Market that pertain to stock prices and market return in the period 2014-2018. The study used simple regression analysis to examine the relationship between independent and dependent variables. Among the most prominent findings of the study, there is an impact of the social responsibility disclosure in reducing risks, as well as an effect of the dimensions of social responsibility: the environment, customers and employees in reducing risks.
\end{abstract}

Keywords: social responsibility disclosure, risk, Jordanian commercial banks, ASE

\section{Introduction}

After the financial crisis that led to the downturn in the global economy in 2008, SR activities became a remedy for firms to improve their reputation (Burianova \& Paulik, 2014). Various firms, particularly in the banking sector, Loss of confidence in customer's eyes because the global crisis arose from the financial markets, which led to community losing confidence in the banking sector. As the investments decreased, the economy was weakened, which is why the social responsibility (SR) of banks was used as a means for banks to restore their credibility (Comett, et al., 2014).

Most banks have discovered mechanisms' risk management (RM) for efficiently handling financial risks (Wong, 2014; Bischoff, 2008; Clearly \&malleret, 2007). In addition, discussing risk issues, especially non-financial risks such as environmental and social responsibility risks, among the issues discussed by the Board of Directors is one of the biggest challenges facing companies today, such as social and environmental issues (Pricewaterhouse Coopers, 2007). RM is a leading indicator, like social risk, for many companies (Anderson \& Anderson, 2009). It is hard to discriminate between non-financial and financial issues, because if non-financial issues (for instance environmental and social issues) are not resolved, this will later lead to these problems becoming financial issues (Brammer et al., 2012).

\section{Problem of the Study}

One of the biggest challenges facing banks at the present time is the introduction of risks such as social issues in decision-making, and neglecting non-financial risks, and not looking for solutions to them will lead to turning them into financial problems. The inter-firm issue is how to engage non-financial risks in decision-making, which is why social and environmental issues have become one of the challenges for companies today (Wong, 2014; pricewaterhouse \& Coopers, 2007)).

Al-Kadash (2003) has indicated that corporate social responsibility has a positive and important relationship with risk management, which may also indicate that banks that may have a low level of SR may face some risks. Barakat et al (2015) study furthermore present that the level of SR disclosure in Jordanian firms is low, and accordingly banks may face some problems if the level of their exercise of social responsibility is low and disclosed. 


\section{Literature Review and Hypothesis of the Study}

\subsection{Social Responsibility Disclosure}

Dealing with social responsibility as a basic requirement of the company, for instance, Crowther and Aras (2008) believe that companies have become integrating environmental and social activities with their business operations, and stakeholder interactions are automatic. It also includes the efforts made by companies in developing appropriate methods to disclose environmental and social activities. These methods help companies to improve social responsibility activities autonomously and independently, and these activities are more effective than activities related to social responsibility imposed by the government (Shahwan, 2018; Armstrong \& Green, 2012).

Previous studies focused on corporate social responsibility mainly in developed countries such as the United Kingdom, the United States, Canada, Japan and some European countries. (Bennentt\&Unerman, 2004; Echave\&Bhati, 2010; Hegde et al., 1997; Hackston\& Milne, 1996; Gray et al., 1995; O'Dwyer, 2002). Previous studies have gathered ideas on the application of corporate social responsibility and its economic benefits, such as (Babington et al., 2014; Gray et al., 2009; Parker, 2011). The researchers found that various methods for evaluating the effect of CSR on the performance of the firms and society in developed countries were developed, and by comparing developing countries with developed ones, developing countries lacked the resources and tools to implement social responsibility and assess their effect on society (Belal\&Owein, 2009; Kisenyi\& Gray, 1998).

In this regard, the developing countries have different social norms and expectations unlike developed countries as what reported by Jamali and Mirshak (2007), and lack of awareness towards social responsibility, therefore increasing awareness of social responsibility will lead to successful social responsibility application and lead to the development of society and country. According to the study of Gray et al. (1995), the topic of disclosure of social responsibility has gained an increasing interest in academic and commercial fields, because the disclosure includes information about products and services, human resources, community activities and environmental reports (Shahwan, 2019; Al Ramahi, 2018 ; Jamali \& Mirshak, 2007).

Social responsibility can be disclosed through corporate social responsibility reports, and these reports are indicators for the public about the activities provided by the company and give a picture of them. Disclosure of corporate social responsibility is practiced to provide information to the public regarding environmental and social activities, and CSR reports often include disclosures on environmental activities, employee activities, and ethical issues (Gray et al., 1996). Gray (1987) mentioned that one of the goals of corporate social responsibility is to improve the company's reputation and provide information to stakeholders, as social responsibility aims to provide information related to the company's activities, and social responsibility is performed considering the existence of a social contract between the company and society. The SR disclosure process assesses the impact of SR activities, measures the effectiveness of SR programs, reports on social responsibility, and provides internal and external information systems to conduct a comprehensive assessment of possible impacts on the company's resources and sustainability (Shahwan, 2019; Jenkins \&Yakovleva, 2006).

\subsection{Risk and Risk Management}

Most companies have recently become aware of the increasing value RM, so companies have established RM department to monitor the risk level to which companies are exposed. Risk could be described as a facing to a loss or arising economic gain from business activities of a company (Perry \& Hayes, 1985; Heale, 1982). RM is the mechanism where risk is identified, evaluated and prioritized in the event of uncertainty. In (2007) The International Organization for Standardization (ISO), clarified RM as: the impact of uncertainty on the company's goals, which leads to economic coordination to reduce the effectiveness of events with negative impact and to monitor and control them effectively. Furthermore, the main goal of RM is to ensure that the main objective of the company is not deviated (Antunes\& Gonzalez, 2015).

According to Williams et al. (2006) there are three types of risks, first: the risks that companies have to manage. These risks often come from regulatory agencies or governments, and environmental risks are classified under this category. Second: Classic risks are the risks accompany any commercial business dealing with funds such as theft and internal and external fraud, and these risks are not subject to external laws, so companies create their own systems to manage these risks. Third: Risks managed by risk management models such as the Integrated Enterprise Risk Management (ERM) model established by the Treadway Organization Committee (COSO, 2004). In addition, (ISO26000) (2015) identified a number of risks in various fields that are related to non-financial risks related to corporate social responsibility. These areas include social commitment, customer relations, nature protection, human rights, honest market practices and business relationships. 


\section{Study Hypotheses}

Based on what has been discussed in the previous (Literature review), and the problem of the study, the following hypotheses were set:

H0: There is no statistically significant effect of social responsibility accounting in its dimensions (environment, customer environment, employee environment) at $(\alpha \leq \% 5)$ on risk reduction in commercial banks listed on the Amman Stock Exchange (ASE).

H01: There is no statistically significant effect of social responsibility accounting with its environmental dimension at $(\alpha \leq \% 5)$ on risk reduction in commercial banks listed on the ASE.

H02: There is no statistically significant effect of social responsibility accounting in its dimension (customer environment) at $(5 \% \geq \alpha)$ on reducing risks in the commercial banks listed on the ASE.

H03: There is no statistically significant effect of social responsibility accounting in its dimension (employee environment) at $(5 \% \geq \alpha)$ on risk reduction in commercial banks listed on the ASE.

\section{Methodology}

The study followed the descriptive and analytical method in order to test the hypotheses. The study data were collected from the annual financial reports of commercial banks operating in Jordan listed on the ASEduring the study period (2014-2018) and available on the website of the ASE. The number of banks reached 13 banks.

\subsection{Study Variables and Their Measurement}

\subsubsection{Dependent Variable (Risk Reduction)}

Risks (Beta): All risks that affect all loans regardless of the conditions of the borrowing bank due to economic, political and social factors that are difficult to control and can be measured through:

5.1.1.1 Calculating the daily return (Ri) of commercial bank shares during the study period through:

$$
++-\frac{P_{2}-P_{1}}{P_{1}}
$$

As $\mathrm{P} 2$ represents the closing price of the current day, P1 represents the closing price of the previous day.

5.1.1.2 Calculating the daily return for the general index $(\mathrm{Rm})$ on the ASEthrough:

$$
\frac{P_{I N X 2}-P_{I N X 1}}{P_{I N X 1}}
$$

As PINX2 represents the general index for the current day, PINX1 represents the general index for the previous day.

5.1.1.3 Calculating the slope between the daily return of the shares of commercial banks and the return of the general index for each year of study through the use of the command (Slope) in Excel software:

$$
\begin{aligned}
& \text { Beta = slope (Ri;Rm) } \\
& \text { (Stephan et al. } 2008)
\end{aligned}
$$

\subsubsection{Independent Variable (Accountability of Social Responsibility)}

The business establishment's commitment to the community, in which it operates, is represented by contributing to a wide range of social activities such as improving health services, combating pollution, fighting poverty, solving the housing and transportation problem, creating job opportunities, and others, and it was measured through:

5.1.2.1 Social responsibility towards the environment: Where No. 1is given to the bank that discloses its activities towards the environment, and No. 0 is given to others.

5.1.2.2 Social responsibility towards customers: where No. 1 is given to the bank that discloses it has carried out activities towards the customer's environment and No. 0 is given to others.

5.1.2.3 Social responsibility towards employees: where No. 1 is given to the bank that discloses its activities towards the employee environment and No. 0 is given to others. 


\subsection{Study Model}
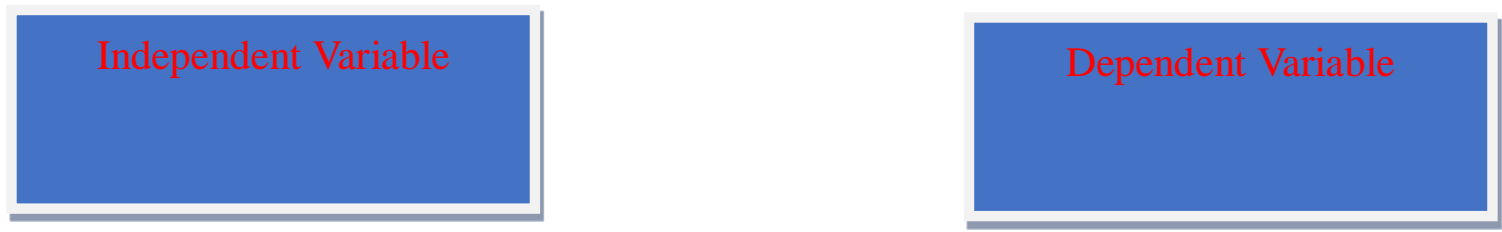

\section{Disclosure of social} responsibility:

1. Towards environment.

2. Towards customers.

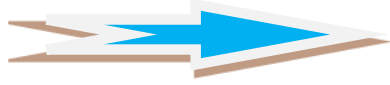

\section{Reducing risks}

3. Towards employees.

\section{Results and Discussion}

\subsection{Normal Distribution Test}

The researcher applied the normal distribution test for all variables, where the values of Skewness and Kurtosis were used. Where data is subject to normal distribution if the Skewness values are less than 3 and the Kurtosis values are less than 10 (Hair et al., 2010). Table 1 indicates the results of the normal distribution test for the study variables:

Table 1. The normal distribution of the study variables

\begin{tabular}{ccc}
\hline The Variable & $\begin{array}{c}\text { Skewness statistical } \\
\text { value }\end{array}$ & Kurtosisstatistical value \\
\hline Risks & -1.337 & 1.676 \\
Social responsibility towards the environment & -0.187 & -0.475 \\
Social responsibility towards customer environment & 0.429 & 0.096 \\
Social responsibility towards the employee environment & -0.066 & -0.644 \\
Social responsibility as a whole & -0.459 & -0.625 \\
\hline
\end{tabular}

The above table indicates that all Skewness values were less than 3 as the highest value of the contortion reached -1.337 for the risk variable. These results indicate that all study variables are intact from normal distribution problems.

\subsection{Correlation Coefficients}

Correlation coefficients often refer to the test of the interference of Multicollinearity variables, where the correlation indicates, if it exceeds $90 \%$, that there are problems of multiple linear correlation. The following Table 2 presents the correlation matrix between variables of the study: 
Table 2. Correlation between study variables*

\begin{tabular}{cccc}
\hline Variables & $\begin{array}{c}\text { Social responsibility } \\
\text { towards the environment }\end{array}$ & $\begin{array}{c}\text { Social responsibility } \\
\text { towards customer } \\
\text { environment }\end{array}$ & $\begin{array}{c}\text { Social responsibility } \\
\text { towards the employee } \\
\text { environment }\end{array}$ \\
\hline $\begin{array}{c}\text { Social responsibility } \\
\text { towards the environment } \\
\text { Social responsibility } \\
\text { towards customer } \\
\text { environment }\end{array}$ & 1 & & \\
$\begin{array}{c}\text { Social responsibility } \\
\text { towards the employee } \\
\text { environment }\end{array}$ & 0.078 & 0.322 & 1 \\
\hline
\end{tabular}

Through the results of the above Table 2, it is clearly shown that the highest correlation rate was between social responsibility, customer environment, and social responsibility towards employee environment (0.322), and it was less than $90 \%$, which indicates the absence of multiple linear correlation problems between study variables. Hence the integrity of the regression equation from falling into a false regression.

\subsection{Study Hypotheses Test}

To test the study hypotheses, a simple regression analysis test was performed at the level of statistical significance $(0.05 \leq \alpha)$, that is, at a confidence level of at least $95 \%$ and an error rate of no more than $5 \%$, as follows:

\subsubsection{Results of Main Hypothesis Test}

Table 3 presents the results of the regression analysis test to determine the extent of the impact of the disclosure of activities related to social responsibility in reducing risks in Jordanian banks listed on the Amman Stock Exchange:

Table 3. Results of the analysis of the effect of disclosing activities related to social responsibility in risk reduction

\begin{tabular}{ccccc}
\hline Dependent Variable & Independent Variable & B & T & Sig. \\
\hline Reducing risks & Constant & 0.96 & 70.49 & 0.000 \\
& Social Responsibility & 0.41 & 4.61 & $0.000^{* * *}$ \\
R2 & 0.799 & & \\
Sig & 0.000 & & \\
F & 21.223 & & \\
\hline
\end{tabular}

The above Table 3 indicates that there is a significant and positive relationship of social responsibility in reducing risks, as the value of $\mathrm{F}=21.223$ and the value of $\mathrm{Sig}=0,000$, which means that banks that exercise social responsibility with a high degree tend to reduce risks. The table also indicates that the explanatory R2 value reached $79.9 \%$, which means that social responsibility contributes $79.9 \%$ to reducing risks and that there are other methods other than social responsibility contributing $20.1 \%$. From the above, it is evident that the main zero hypothesis is rejected and the main alternative hypothesis is accepted. "There is a statistically significant effect of disclosing activities related to social responsibility in reducing risks in Jordanian banks listed on the ASE." This indicates the positive impact of the social responsibility disclosure, and this finding is consistent with a study (Bebbingtinet., 2008).

The following are the results of the sub-hypothesis test:

\subsubsection{Regression Analysis of the Impact of Social Responsibility Towards the Environment on Risk Reduction}

Table 4 presents the results of the regression test to determine the extent of the impact of the disclosure of activities related to social responsibility towards the environment in reducing risks in banks listed on the ASE: 
Table 4. Results of the analysis of the effect of disclosing activities related to social responsibility towards the environment in reducing risks

\begin{tabular}{ccccc}
\hline Dependent Variable & Independent Variable & B & T & Sig. \\
\hline Reducing risks & Constant & 0.95 & 80.03 & 0 \\
& Social responsibility towards the & 0.15 & 2.74 & $0.004 * * *$ \\
environment & & & \\
R2 & 0.756 & & \\
Sig & 0.004 & & \\
F & 7.523 & & \\
\hline
\end{tabular}

The results in the above table indicate that the independent variable (social responsibility towards the environment) explained an amount of $75.6 \%$ of the change in risk reduction. It also indicated that social responsibility towards the environment was statistically significant in the reduction of risks, as the value of $\mathrm{F}=7.523$ and the value of sig $=$ 0.004 , this result indicates that banks resort to social responsibility towards the environment as an attempt to mitigate and avoid risks. Based on the above, the first zero hypothesis was rejected and the alternative hypothesis was accepted. "There is a statistically significant effect of disclosing activities related to SR towards the environment in reducing risks in Jordanian banks listed on the ASE." This is a good indication of the concerns of banks in developing technologies related to energy-saving and water-saving systems. The bank also participates in national initiatives and campaigns to protect the environment. The nature of the bank's activity, its negative impact on the environment is very little, unlike industrial companies.

\subsubsection{Regression Analysis of the Impact of SR Activities on Clients in Risk Reduction}

Table 5 shows the results of the regression analysis test to determine the extent of the impact of the disclosure of activities related to social responsibility towards customers in reducing risks in Jordanian banks listed on the ASE:

Table 5. Results of the analysis of the impact of activities related to social responsibility towards customers in reducing risks

\begin{tabular}{ccccc}
\hline Dependent Variable & Independent Variable & B & T & Sig. \\
\hline Reducing risks & Constant & 0.97 & 85.85 & 0 \\
& $\begin{array}{c}\text { Social responsibility towards } \\
\text { customer environment }\end{array}$ & 0.16 & 4.80 & $0.000^{* * *}$ \\
R2 & 0.601 & & \\
Sig & 0.000 & & \\
F & 23.011 & & \\
\hline
\end{tabular}

The results shown in the above table indicate that the independent variable (social responsibility towards the customer's environment) explained $60.1 \%$ of the change in risk reduction. It also indicated that social responsibility was of a positive impact with statistical significance in reducing risks, as the value of $-23.011 \mathrm{~F}=$ and the value of sig $=0.000$, this result indicates that banks resort to social responsibility towards customers as an attempt to mitigate and avoid risks. Based on the above, the second null hypothesis was rejected and the alternative hypothesis was accepted. "There is a statistically significant effect of disclosing activities related to SR towards the customer environment in limiting the risks in Jordanian banks listed on the ASE." This means that there is an interest on the part of bank employees in customers and that there is an obligation on the part of the bank to solve customer problems and speed up the completion of transactions for them.

6.3.4 Regression Analysis of the Impact of SR Activities on the Employee Environment on Risk Reduction

Table 6 presents the results of the regression analysis of the impact of the disclosure of activities related to social responsibility towards the employee environment in reducing risks in Jordanian banks listed on the ASE: 
Table 6. Results of the analysis of the impact of the disclosure of activities related to social responsibility towards the employee environment in reducing risks

\begin{tabular}{ccccc}
\hline Dependent Variable & Independent Variable & B & T & Sig. \\
\hline Reducing risks & Constant & 0.959 & 11.18 & 0.000 \\
& $\begin{array}{c}\text { Social responsibility towards the } \\
\text { employee environment }\end{array}$ & 0.81 & 3.74 & $0.000^{* * *}$ \\
R2 & & & \\
Sig & & 0.284 & \\
F & & 0.000 & \\
& & & 13.961 \\
\hline
\end{tabular}

The results shown in the above table indicate that the independent variable (social responsibility towards the employee environment) explained $28.4 \%$ of the change in risk reduction. It also indicated that social responsibility towards the employee environment was of a positive impact with statistically significant effect on risk reduction, where the value of $F=13.961$ and the value of sig $=0.000$, this result indicates that social responsibility towards the employee environment contributes to reducing risks. Based on the foregoing, the third null hypothesis was rejected and the alternative hypothesis was accepted. "There is a statistically significant effect of disclosure of activities related to social responsibility towards the employee environment to reduce risks in Jordanian banks listed on the ASE." This is a good indication of the interest of banks in their employees and the positive impact. By disclosing SR activities in risk reduction.

\section{Conclusions and Recommendation}

Disclosing more information about the social responsibility towards the employees and society probably will be reflected on employees' performance, it may decrease or limit the losses from pilferage or sabotage of the employees; besides it will amplify the employees' loyalty for the companies. That will reflect on the improved interest of the shareholders. Therefore, RM should work to expect these issues and solve it; consequently, RM must support by enhanced awareness of the social problems, strengthening the innovation and learning environment through a dedication to social responsibility (Zadek, 2000). By having the aims of social responsibility, companies could reduce their risk, and this could be reflected in their performance (Arouri \& Pijourlet, 2015).

Also, the stakeholder's theory states that the firms must also take into consideration the non-financial stakeholders (for instance the non-governmental organization, the community) when the firm prepares any activity, Since this will represent the company's credibility and that the burden and risk from non-financial stakeholders (Freeman, 1984, 2010). Focusing on the company's internal environment, such as employees can not be enough to mitigate the risks that the organization can face. In other words, the weakness of knowledge towards the external environment and the society will raise the risks faced by the firm, such as the loss of the company's credibility, the financial performance, and reputation of the companies, and shareholders wealth (House \& Frankental, 2000).

Further, the study recommends the necessity of conducting training and introductory courses for bank managers to introduce them to the importance of SR and its impact in reducing risks in addition to the importance of social responsibility in improving the environment and society. The study recommends that banks continue to disclosing about SR and work to develop methods of practicing SR and increase the disclosure of the information of SR activities because of this positive impact in reducing risks and raising competitiveness, which would positively affect the financial performance of banks. The researcher recommends applying this study to the different sectors in Jordan and in other developing countries.

\section{Acknowledgements}

This research was funded by Deanship of Research in Zarqa University. I would like to acknowledge Zarqa University who provided insight and expertise that greatly assisted the research.

\section{References}

Al Ramahi, N., Alaboud, E., Owais, W., AlRefae, K., \& Shahwan, Y. (2014). The Results of Applying the Principles of Corporate Governance in Corporations Listed on the First Market in the Amman Stock Exchange. Research Journal of Finance and Accounting, 5(14), 41-53. 
Al-Khadash, H. A., \& Al-Yarmouk, A. (2003). The accounting disclosure of social and environmental activities a comparative study for the industrial Jordanian shareholding companies. Abhath Al-Yarmouk Journal: Humanities and Social Sciences, 19(2), 21-39.

Al-Ramahi, N., Barakat, A., \& Shahwan, Y. (2014). The impact of corporate governance principles application on financial performance of public shareholding companies listed in Amman stock exchange. European Journal of Accounting Auditing and Finance Research, 2(6), 100-117.

Anderson, D. R., \& Anderson, K. E. (2009). Sustainability risk management. Risk Management and Insurance Review, 12(1), 25.

Antunes, R., \& Gonzalez, V. (2015). A Production model for construction: A theoretical framework. Buildings, 5(1), 209-228.

Armstrong, J. S., \& Green, K. C. (2012). Effects of corporate social responsibility and irresponsibility policies. Journal of Business Research, 66(10), 1922-1927.

Arouri, M., \& Pijourlet, G. (2017). CSR performance and the value of cash holdings: International evidence. Journal of Business Ethics, 140(2), 263-284.

Barakat, F. S., Pérez, M. V. L., \& Ariza, L. R. (2015). Corporate social responsibility disclosure (CSRD) determinants of listed companies in Palestine (PXE) and Jordan (ASE). Review of Managerial Science, 9(4), 681-702.

Bebbington, J., Unerman, J., \& O’Dwyer, B. R. E. N. D. A. N. (2014). Introduction to sustainability accounting and accountability. In Sustainability accounting and accountability (pp. 21-32). Routledge.

Belal, A. R., \&Momin, M. (2009). Corporate social reporting (CSR) in emerging economies: A review and future direction. Research in accounting in emerging economies, 9(1), 119-143.

Bischoff, H. J. (Ed.). (2008). Risks in modern society (Vol. 13). Springer Science \& Business Media.

Brammer, S., Jackson, G., \&Matten, D. (2012). Corporate social responsibility and institutional theory: New perspectives on private governance. Socio-Economic Review, 10(1), 3-28.

Burianová, L., \&Paulík, J. (2014). Corporate Social Responsibility in commercial banking-a case study from the Czech Republic. Journal of Competitiveness.

Cleary, S., \& Malleret, T. (2007). Global Risk: business success in turbulent times. Palgrave Macmillan.

Committee of Sponsoring Organizations of the Treadway Commission. (2004). Enterprise risk management Integrated framework. Retrieved from www.coso.org/publications/erm/cosoenn executivesummary.pdf

Cornett, M. M., Erhemjamts, O., \& Tehranian, H. (2014). Corporate social responsibility and its impact on financial performance: Investigation of US commercial banks. Unpublished manuscript.

Crowther, D. \& Aras, G. (2008). Corporate Social Responsibility. ventus publishing aps. Capital Region of Denmark.

Echave, J. O., \& Bhati, S. S. (2010). Determinants of social and environmental disclosures by Spanish companies.

Freeman R. E. (1984). Strategic Management: A Stakeholder Approach. Boston, United States: Pitman.

Freeman, R. E. (2010). Strategic management: A stakeholder approach. Cambridge University Press.

Gray, J. A. (1987). The psychology of fear and stress (Vol. 5). CUP Archive.

Gray, R., Dillard, J., \& Spence, C. (2009). Social accounting research as if the world matters: an essay in Postalgia and a new absurdism. Public Management Review, 11(5), 545-573.

Gray, R., Kouhy, R., \& Lavers, S. (1995). Constructing a research database of social and environmental reporting by UK companies. Accounting, Auditing \& Accountability Journal.

Gray, R., Owen, D., \& Adams, C. (1996). Accounting \& accountability: changes and challenges in corporate social and environmental reporting. Prentice Hall.

Hackston, D., \& Milne, M. J. (1996). Some determinants of social and environmental disclosures in New Zealand companies. Accounting, Auditing \& Accountability Journal.

Heale, J. R. (1982). Contingency funds evaluation. Transaction of American Association of Cost engineers, 9(4), 387-399. 
Hegde, P., Bloom, R., \& Fuglister, J. (1997). Social financial reporting in India: A case. The International Journal of Accounting, 32(2), 155-172.

House, F., \& Frankental, P. (2000). Human Rights - Is It Any of Your Business? United Kingdom: Amnesty International.

ISO. (2015). ISO 26000 Guidance on Social Responsibility. Switzerland: International Organization for Standardization.

Jamali, D., \& Mirshak, R. (2007). Corporate social responsibility (CSR): Theory and practice in a developing country context. Journal of Business Ethics, 72(3), 243-262.

Jenkins, H., \& Yakovleva, N. (2006). Corporate social responsibility in the mining industry: Exploring trends in social and environmental disclosure. Journal of Cleaner Production, 14(3-4), 271-284.

Kisenyi, V., \& Gray, R. (1998). Social disclosure in Uganda? A research note on investigating absence.

O'Dwyer, B. (2003). Conceptions of corporate social responsibility: the nature of managerial capture. Accounting, Auditing \& Accountability Journal.

Parker, L. D. (2011, March). Twenty-one years of social and environmental accountability research: A coming of age. In Accounting Forum (Vol. 35, No. 1, pp. 1-10). Taylor \& Francis.

Perry, J. G., \& Hayes, R. W. (1985). Risk and its management in construction projects. Proceedings of Institution of Civil Engineers, 78, 499-521.

PricewaterhouseCoopers, L. L. P. (2007). What works: Healing the healthcare staffing shortage. PricewaterhouseCoopers.

Shahwan, Y. (2018). The Mediating Effect of Investment Decisions and Financing Decisions on the Influence of Capital Structure Against Corporate Performance: Evidence From Jordanian Listed Commercial Banks. Academy of Accounting and Financial Studies Journal.

Shahwan, Y. (2019). The Moderating Effects of Dividend Policy on the Impact of Financial Disclosure Towards Corporate Value: A Study of Listed Jordanian Industrial Firms.

Unerman, J., \& Bennett, M. (2004). Increased stakeholder dialogue and the internet: towards greater corporate accountability or reinforcing capitalist hegemony?. Accounting, Organizations and Society, 29(7), 685-707.

Williams, R., Bertsch, B., Dale, B., Van Der Wiele, T., Van Iwaarden, J., Smith, M., \& Visser, R. (2006). Quality and risk management: What are the key issues?. The TQM magazine, 18(1), 67-86.

Wong, A. (2014). Corporate sustainability through non-financial risk management. Corporate Governance: International Journal of Business in Society, 14(4), 575-586.

Zadek, S. (2000). Doing good and doing well: Making the business case for corporate citizenship. Conference Board. 